\title{
Acne keloidalis nuchae: clinical and dermoscopic features
}

\author{
Chourouk Chouk, Noureddine Litaiem, Mariem Jones, Faten Zeglaoui
}

Department of Dermatology, Charles Nicolle Hospital, University of Tunis El Manar, Faculte de Medecine de Tunis, Tunis, Tunisia

\section{Correspondence to}

Dr Noureddine Litaiem, noureddine.litaiem@gmail.com

Accepted 3 September 2017

\section{DESCRIPTION}

Two patients presented to our department with alopecia. The first patient was a 33-year-old man with 1-year history of pruritic small erythematous follicular papules on the neck (figure 1). The second patient was a 56-year-old man with a 5-year history of large keloidal plaque with pustular and crusted lesions causing alopecia (figure 1). Dermoscopy revealed on both cases perifollicular pustules and a vascular pattern composed of dotted vessels on the scalp. In the first case, a white halo surrounding hair follicules was seen (figure 2). In the second case, dermoscopy revealed tufted hairs (figure 2), the diagnosis of acne keloidalis nuchae (AKN) was made. In both cases, close hair cutting was discouraged, and topical benzoyl peroxide $2.5 \%$ and adapalene $1 \%$ were prescribed, leading to a limited number of new lesions and a marked relief of pruritus. Intralesional triamcinolone $(10 \mathrm{mg} /$ $\mathrm{mL}$ ) injections were associated in the second case resulting in a slight decrease of the thickness of the plaques.

AKN is an idiopathic chronic inflammatory process affecting the nape of the neck and the occipital scalp. ${ }^{1}$ The diagnosis is usually made clinically. Dermoscopy is a non-invasive tool widely used in the diagnosis of skin tumours. ${ }^{2}$ Recently, its applicability also extended to the field of hair disorders. ${ }^{3}$ Dermoscopy is a useful aid to the clinical diagnosis, especially in detecting the early signs of perifollicular fibrosis, thus limiting the need of skin biopsy in doubtful cases. ${ }^{3}$

\section{Learning points}

In early stage of acne keloidalis nuchae (AKN), dermoscopy shows perifollicular pustules and white halo surrounding hair follicules corresponding to perifollicular fibrosis. These findings are more apparent when additional pressure on the dermoscope is applied.

- In advanced stage of AKN, dermoscopy typically reveals the presence of tufted hairs.

- The dilatation of follicular ostia can be seen in early lesions but most common in advanced stages of AKN.

\section{Contributors CC and NL drafted the manuscript. MJ provided} comprehensive analysis of the dermoscopic features. FZ revised the manuscript and approved the final draft. All authors contributed and accepted the final draft of the manuscript.

Competing interests None declared.
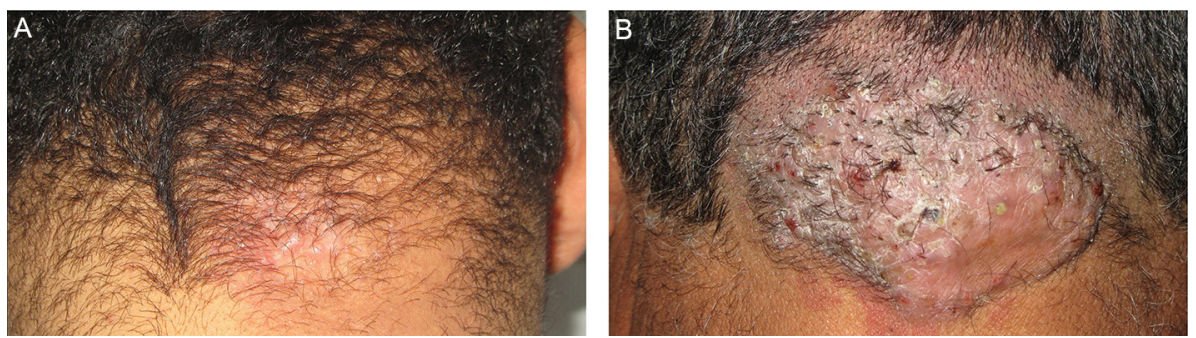

Figure 1 Clinical aspect of acne keloidalis nuchae. (A) Alopecia and perifollicular erythematous papules on the neck. (B) Large keloidal plaque with pustular and crusted lesions causing alopecia.
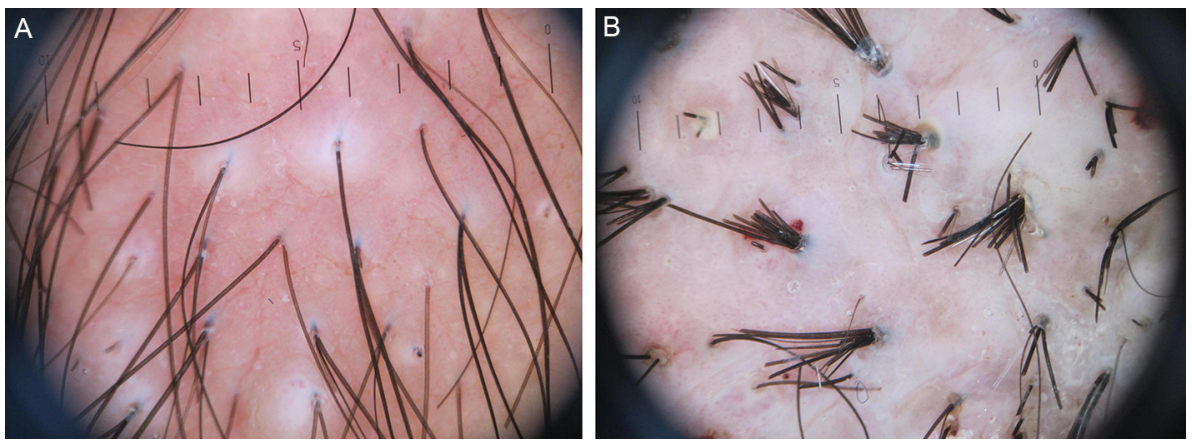

Figure 2 Dermoscopic features of acne keloidalis nuchae. (A) A white halo surrounding hair follicules and dilated follicular ostia filled with keratin associated with black dots. (B) Perifollicular pustules and tufted hairs. 
Patient consent Obtained.

Provenance and peer review Not commissioned; externally peer reviewed.

(C) BMJ Publishing Group Ltd (unless otherwise stated in the text of the article) 2017. All rights reserved. No commercial use is permitted unless otherwise expressly granted.

\section{REFERENCES}

1 Perkins W. Acne keloidalisnuchae. In: Treatment of skin disease: comprehensive therapeutic strategies. 4th edn: Elsevier Limited, 2014.

2 Litaiem N, Mansour Y, Jones M, et al. Dermoscopic signs of lichen planus. BMJ Case Rep 2016;2016:bcr2015213923.

3 Assouly P. Dermatoscopy of hair and scalp. Ann Dermato/Venereol 2012;139:652-67.

Copyright 2017 BMJ Publishing Group. All rights reserved. For permission to reuse any of this content visit

http://group.bmj.com/group/rights-licensing/permissions.

BMJ Case Report Fellows may re-use this article for personal use and teaching without any further permission.

Become a Fellow of BMJ Case Reports today and you can:

- Submit as many cases as you like

- Enjoy fast sympathetic peer review and rapid publication of accepted articles

- Access all the published articles

Re-use any of the published material for personal use and teaching without further permission

For information on Institutional Fellowships contact consortiasales@bmjgroup.com

Visit casereports.bmj.com for more articles like this and to become a Fellow 